\title{
Ductoscopy Coupled to Duct Lavage and Duct Brushing in Pathologic Nipple Discharge: Our Experience
}

\author{
Stefanos Zervoudis ${ }^{1,2,3^{*}}$, Georgios latrakis ${ }^{2,3}$, Jean-Pierre Daures ${ }^{5}$, Anastasia Bothou ${ }^{3,4}$, Vasilis Aranitis ${ }^{2}$, \\ Xaralambos Patralexis ${ }^{2}$, Georgios Tsatsaris ${ }^{4}$, Iordanis Navrozoglou', Panagiotis Tsikouras ${ }^{4}$, Minas Paschopoulos ${ }^{1}$ \\ ${ }^{1}$ University of Ioannina, Greece \\ ${ }^{2}$ Rea Hospital, Athens, Greece \\ ${ }^{3}$ University of West Attica, Athens, Greece \\ ${ }^{4}$ University of Alexandroupolis, Greece \\ ${ }^{5}$ University of Montpellier-Nimes, France
}

${ }^{*}$ Corresponding author:

Prof. Stefanos Zervoudis MD, PhD

Rea Hospital, 383-Syggrou Avenue

Palaio Faliro 17564, Greece

Tel: +6944308777

Fax: +302108981178

E-mail: szervoud@otenet.gr

\section{Rezumat}

Ductoscopie efectuată împreună cu lavajul și periajul ductului în descărcarea mamelonului patologic: experiența noastră

Scop: prezentarea experienței noastre în gestionarea descărcării patologice a mamelonului, folosind procedura D-DL-DB: „ductoscopie” (D) efectuată împreună cu „lavajul ductului” (DL) şi „periaj ductului" (DB) pentru diagnostic etiologic. De asemenea, scopul nostru este şi compararea diagnosticul obținut prin D-DL-DB cu histologia finală.

Material şi metodă: Optzeci şi cinci de pacienți cu descărcare unilaterală a mamelonului au fost înscrişi în două unități mamare. Optzeci şi doi din 85 de pacienți au fost supuşi procedurii D-DL-DB, având rezultatul scontat. Diagnosticul final a fost stabilit prin excizia chirurgicală a ductului.

Rezultate: Rezultatele histologice finale au fost: papilom 46,3\%, ectazie ductală $36,5 \%$, cancer mamar $8,5 \%$, leziuni precanceroase 4,9\% şi leziuni benigne mixte $3,8 \%$. Piramidectomia şi ductectomia radicală au fost efectuate în 76 , respectiv şase cazuri. În $80 \%$ din cazuri, rezultatele citologiei DL-DB au fost identice cu histologia finală (Kappa $=0 ; 69 \mathrm{CI}=[0,56-0,82])$. Sensibilitatea D-DL-DB comparativ cu patologia, pentru leziunile canceroase sau precanceroase a fost de 81,8\% (CI = 0,59-1), iar specificitatea a fost de $97,1 \%$ (CI $=0,93-1)$. Folosind scala Koch, concordanța dintre cele două metode (D-DL-DB şi chirurgie) a fost ridicată, iar sensibilitatea a fost în intervalul superior comparativ cu cel prezentat în literatura de specialitate $(58 \%-90 \%)$. 
Concluzie: Experiența noastră confirmă valoarea ridicată a D-DL-DB în gestionarea descărcării organice a mamelonului.

Cuvinte cheie: ductoscopie a sânului, lavajul ductului, periajul ductului, descărcare a mamelonului, microductectomie, piramidectomie

\begin{abstract}
Purpose: to present our experience in the management of pathological nipple discharge using the procedure D.DL.DB: "ductoscopy" (D) coupled to "duct lavage" (DL) plus "duct brushing" (DB) for etiologic diagnosis. Also to compare the diagnosis obtained with D.DL.DB to the final histology.

Material and Method: Eighty-five patients with organic unilateral nipple discharge were enrolled in two Breast Units. 82 of 85 patients were investigated successfully with D.DL.DB. The final diagnosis was performed by surgical excision of the duct.

Results:The final histological results were: papilloma $46.3 \%$, duct ectasia $36.5 \%$, breast cancer $8.5 \%$, precancer lesions $4.9 \%$, and mixed benign lesions 3.8\%. Pyramidectomy and radical ductectomy were performed in 76 and 6 cases respectively. In $80 \%$ of the cases, DLDB cytology results were identical to the final histology. (Kappa=0;69 CI=[0.56 -0.82]. The sensitivity of D.DL.DB versus pathology, for cancer or precancer lesions was $81.8 \%(\mathrm{CI}=0.59-1)$ and the specificity was $97.1 \%(\mathrm{CI}=0.93-1)$. Using Koch scale, the concordance between the two methods D.DL.DB and surgery was high and the sensitivity was in the upper range regarding the literature (58\% to $90 \%)$.

Conclusion: Our experience confirms the high value of D.DL.DB in the management of organic nipple discharge.
\end{abstract}

Key words: breast ductoscopy, duct lavage, duct brushing, nipple discharge, microductectomy, pyramidectomy

\section{Introduction}

Nipple discharge is a common complaint of the women and represents about $9 \%$ of breast consultations (1). Different clinical, imaging and laboratory techniques can be used for the diagnosis of the condition, which differ from each other in terms of feasibility, efficiency and possibly safety. Mammogram, tomosynthesis, magnetic resonance imaging (MRI), high-resolution ultrasound are included in the imaging sensitive techniques for the investigation of probable intraductal lesions.

Furthermore, galactography (2) MRI Galactography (3) and galactography with tomosynthesis (4) could be used to approach the nature and the localization of the lesion. Finally, according to a recent meta-analysis, liquid cytology is a useful diagnostic modality for the detection of breast cancer in patients with pathological nipple discharge, with high specificity, although its sensitivity is moderate (5). The cytology accuracy is increased using the mammary pump (6) to collect about 10 times more cells and deeper in the breast. Actually, unilateral, single duct, sanguineous, serous or sero-sanguineous discharge are included in the indications of ductoscopy (7) However, ductoscopy (Figs. 1-4) is a complementary very interesting technique in many cases (8) and duct lavage during ductoscopy could improve the accuracy of the diagnosis. Moreover duct lavage with duct brushing increase much more the accuracy of the diagnosis (9-10).

The final diagnosis of the organic nipple discharge etiology is achieved by the surgical excision of the pathological lesion with the duct(s) involved. Classically the surgical procedures of Hadfield's major duct subareolar excision (11) and the Lansac's Pyramidectomy (12) are nowadays replaced by the more 


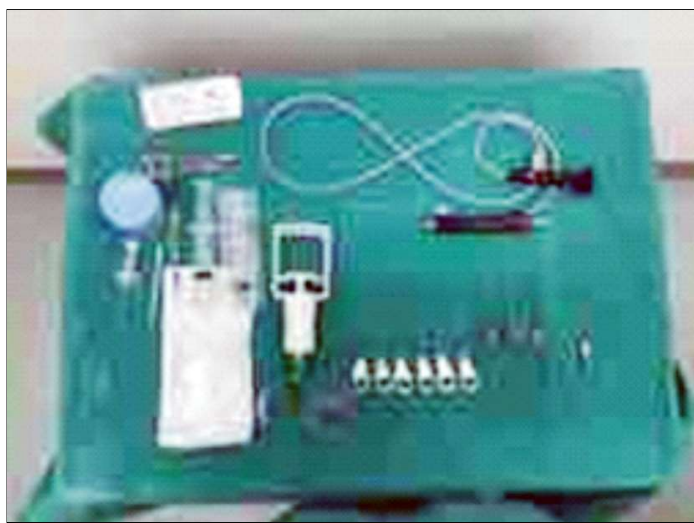

Figure 1. Tools for ductoscopy and duct lavage

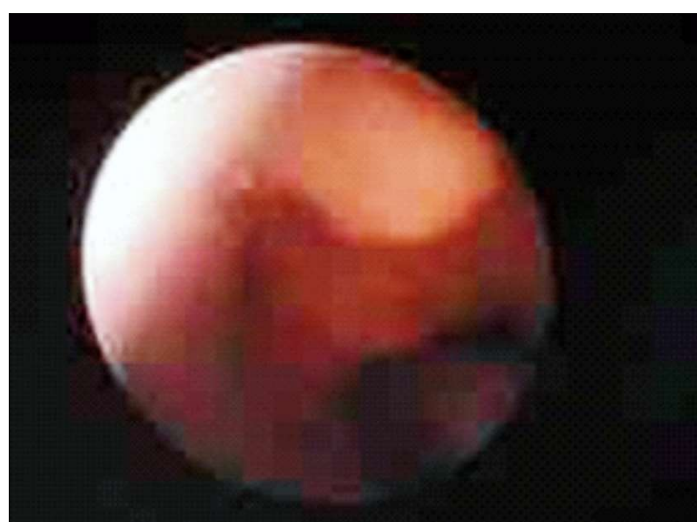

Figure 3. Cancer in ductoscopy

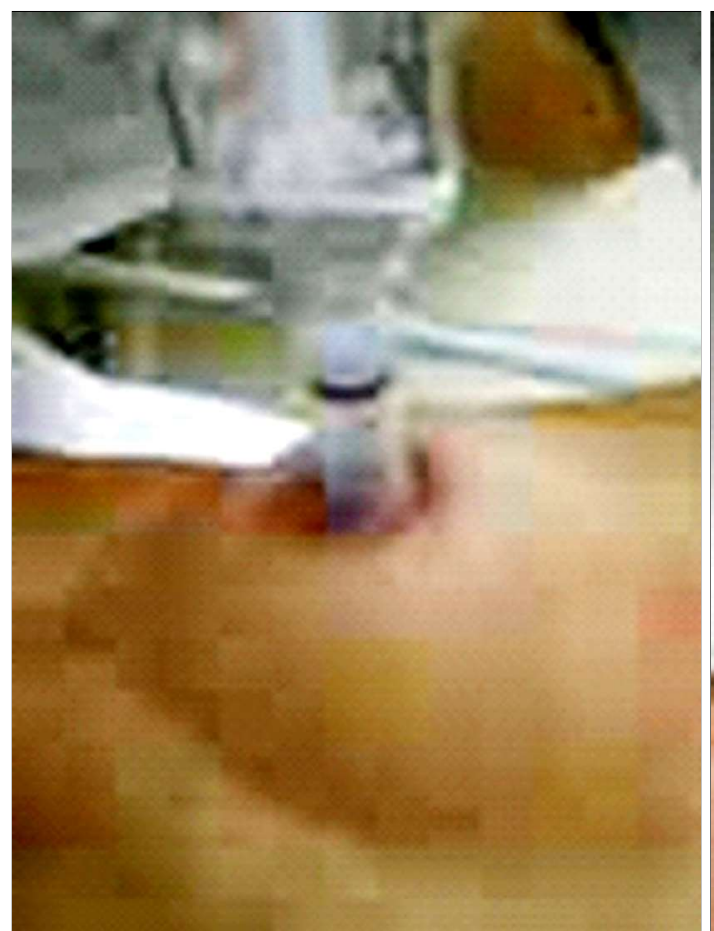

Figure 4. Zervoudis's mammary pump

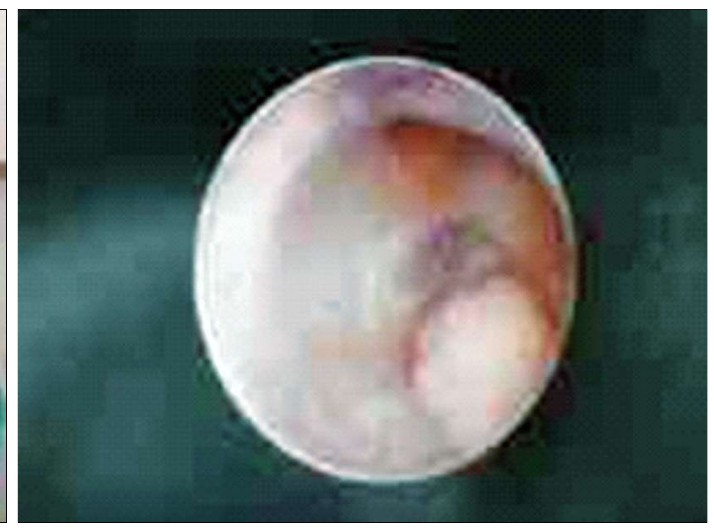

Figure 2. Papilloma in ductoscopy

elective surgical procedure: the minimal invasive microductectomy (13). Furthermore, a transnipple approach could be used to identify, get to and excise with microsurgical technique the elective pathological duct, removing a small pyramide-shaped tissue (Fig. 5) (14).

The ductoscope could help also to guide the minimal surgical procedure. Moreover the latter method has at least the same efficacy as older techniques $(11,15)$ with much better cosmetic results.

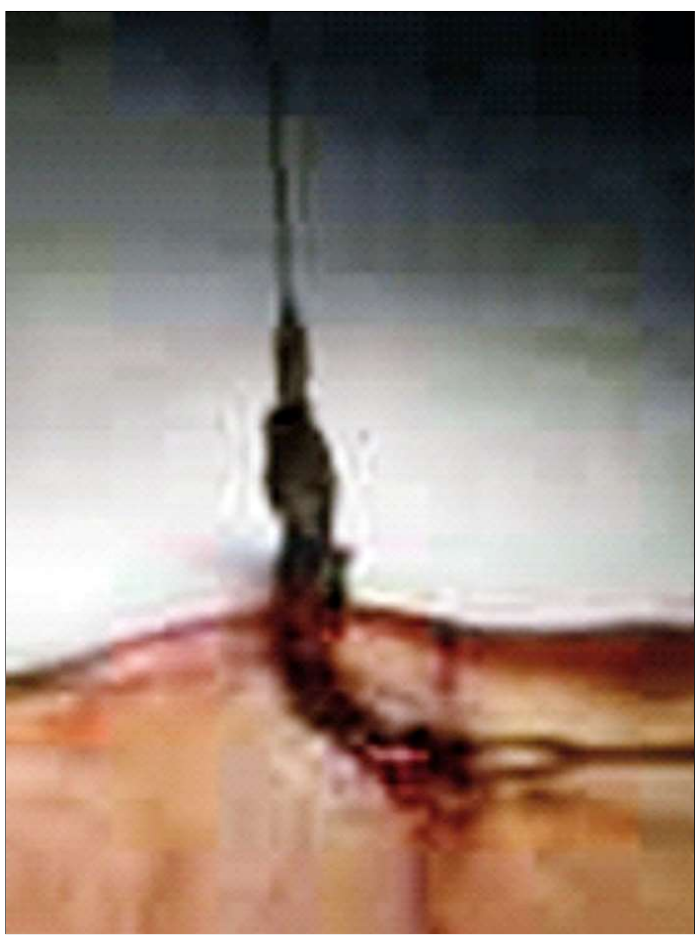

Figure 5. Transnipple pyramidectomy 


\section{Material and Methods}

The aim of this study was to present our experience of management of organic nipple discharge in our units, using ductoscopy and duct lavage with brushing and quote final diagnoses comparing to the final histological result obtained by the surgical excision (pyramidectomy or radical ductectomy).

We included in the study from January 2014 to December 2018 in the breast unit of two Greek hospitals 125 patients which consulted for organic nipple discharge with the followed criteria: uniduct (or from maximun two ducts) spontaneous bloody or serous unilateral nipple discharge. From 125 patients, 85 patients were explored completely with the classical mammography, high resolution ultrasosonography and in many cases galactography and breast MRI. All patients were explored with Ductoscopy coupled with duct lavage and duct brushing.

All patients consent to be explored with all these techniques.

Ductoscopy was performed under slight general anesthesia and the microendoscope was inserted in the pathological duct after gentle dilatation with Bauman dilatators (16). A saline perfusion connected to the endoscope allowed the navigation in the breast ducts and the lesion was recognized. A sample of cells was collected with duct brushing with a very small endobrush (10) and, afterwards, duct lavage of the liquid of the ducts was performed. After a surgical procedure transnipple pyramidectomy (14) was performed. The final diagnosis was established by the pathologoanatomic examination of the specimen after pyramidectomy or ductectomy. The ductoscopic diagnosis coupled with the cytology was compared to the final histology.

The patients' age ranged between 28 and 82 years with a mean age of 54 years.

Ductoscopy with duct lavage plus brushing (D, DL, DB) was successful technically in 82 of the 85 cases $(96.4 \%)$. Furthermore, pyramidectomy was performed in 76 cases of the 82 patients $(92.7 \%)$ and Modified radical ductectomy type Hadfield in 6 cases of the 82 patients. On the contrary in 3 patients of the $85(3.5 \%)$ D and DL, DB was not technically satisfied and so we performed Radical Ductectomy type Hadfield (11). This larger surgery was performed in these patients because the suspicious image during the ductoscopy or technical difficulty to identify the lesion or in case of multiple lesions in multiple ducts.

The anatomopathogical results were blind reading versus the D.DL.DB results.

\section{Statistical Methods}

To estimate the concordance between the two methods, we used the Kappa statistics with its 95\% confidence interval. Our results were compared to the levels of the Koch scale. We estimated the sensitivities and the specificities as percentages with $95 \%$ confidence intervals. We compared specificities and sensitivities between each diagnosis using Chisquare test. The positive predictive value and the negative predictive value were estimated only for Breast cancer or precancer lesions.

Statistical analyses were performed using SAS statistical software version 9.4. by EA2415 Montpellier University and Beau Soleil Biostatistical team.

\section{Results}

Bloody nipple discharge was the most common presenting symptom (52\%). Clear, yellowish and brownish discharge was presented in $18 \%, 8 \%$ and $22 \%$ of the cases respectively. Navigation in the ducts recognized suspicious lesions which included papilloma, papillomatosis, duct ectasia, mixed or non specific lesion and cancer. The lesion was categorized in accordance with international classifications as superficial, elevated or multiple (15).

Regarding the group of 82 patients explored with D. DL.DB we divided it in 2 subgroups: patients who undergo to Transnipple Pyramidectomy TP (76 patients) and those to Radical Ductectomy (6 patients) $\mathrm{RD}$, we had the following results: In 66 
patients of $82: 80 \%$ of the cases, ductal brushing/duct lavage/cytology results were identical to the final histology. (Kappa=0;69 $\mathrm{CI}=(0.56-0.82)$, (Table 1).

Analytically: Papilloma and papillomatosis was the final histological diagnosis in most of the cases: 38 patients (46.3\%) of the 82 patients. The sensitivity was $81.6 \% \mathrm{CI}=(0.69$ $0.94)$ and the specificity $84 \% \mathrm{CI}=(0.73-0.94)$ Moreover Papilloma and Papillomatosis had clinically a bloody nipple discharge in $72 \%$ of cases, $21 \%$ had a serous discharge, and in $7 \%$ and mixt or brown color.

Duct ectasia was the final diagnosis in 30 cases of 82 patients $(36.5 \%)$. The sensitivity was $86.6 \% \mathrm{CI}=(0.74-0.99)$ and the specificity $92.3 \% \mathrm{CI}=(0.85-0.99)$.

Breast cancer (Ductal cancer in situ or invasive) was the final diagnosis in 7 cases of the 82 patients $(8.5 \%)$.

Precancer lesions: Ductal atypical hyperplasia, Lobular cancer insitu was the final diagnosis in 4 cases of the 82 patients (4.9\%).

For breast cancer or precancer lesions the sensitivity was $81.8 \% \mathrm{CI}=(0.59-1)$ and the specificity $97.1 \% \mathrm{CI}=(0.93-1)$.

Mixed lesions (papilloma plus duct ectasia) was the final diagnosis in 3 cases of the 82 patients $(3.8 \%)$.

The sensitivity was $0 \%$ and the specificity $96.2 \% \mathrm{CI}=(0.92-1)$.

Comparing breast cancer or precancer lesion to benign lesion (Table 2) the sensitivity of ductoscopy was $81.8 \% \mathrm{CI}=(0.59-1)$ and the specificity was $97.1 \% \mathrm{CI}=(93.2-1)$.

In our serie of 82 Ductoscopy Duct Lavage Duct Brushing and comparing to the final histological results, the Positive predictive value of diagnosis cancer or precancer was $81.8 \% \mathrm{CI}=(0.59-1)$ and the Negative Predictive value was $2.8 \% \mathrm{CI}=(0-0.06)$.

If we compare the sensitivities between the for groups of lesions:( $81.6 \%$ vs $86.6 \%$ vs $81.8 \%$ vs 0$)$ the $\mathrm{X} 2$ test is significant $(\mathrm{p}=0.0043)$; the sensitivity of the group of mixed lesions is lower than that the others groups.

If we compare the specificities between the four groups of lesions: (0.84 vs 0.923 vs 0.971 vs 0.962$)$ the $\mathrm{X} 2$ test is significant $(\mathrm{p}=0.0285)$;
Table 1. Different lesions in ductoscopy compared to pathology

\begin{tabular}{cccccc}
\hline \multicolumn{7}{c}{ Ductoscopy } \\
\hline pathology & & $\mathrm{P}$ & $\mathrm{E}$ & $\mathrm{C}$ & $\mathrm{M}$ \\
\hline $\mathrm{P}$ & 31 & 2 & 2 & 3 \\
\hline $\mathrm{E}$ & 4 & 26 & 0 & 0 \\
\hline $\mathrm{C}$ & 2 & 0 & 9 & 0 \\
\hline $\mathrm{M}$ & 1 & 2 & 0 & 0
\end{tabular}

P:papilloma, E:duct ectasia; C:breast cancer or precancer lesion, M:mixed lesions

the specificity of the lesions: papilloma (and papillomatosis) was lower than that the specificity of the lesions duct ectasia and cancer .The mean specificity was $89 \%$.

Regarding the group of 3 patients which the DDLB was not achieved for technical problems and a Radical Ductectomy type Hadfield was performed we found in the final histological results: 1 case with cancer (33.3\%) and 2 with papilloma (66.6\%).

\section{Discussion}

Mammogram, tomosynthesis, MRI, highresolution ultrasound, galactography, galactography with tomosynthesis and ductoscopy are included in the imaging sensitive techniques for the investigation of probable intraductal lesions.

Ductoscopy, mammary pump (6), duct brushing (9), and liquid cytology increase the quantity (and the quality) of the cytology specimen (16) and nowadays ductoscopy is a routine procedure in expert centers and countries (17-18). Although the accuracy of ductoscopy and duct sampling depends on the technical procedures and on the experience of the breast surgeons. In the literature the sensitivity ranges from 58 to $95 \%$ (Table 3) $(8,20)$ but in general the procedure of

Table 2. Benign and Malignant lesion in ductoscopy compared to pathology

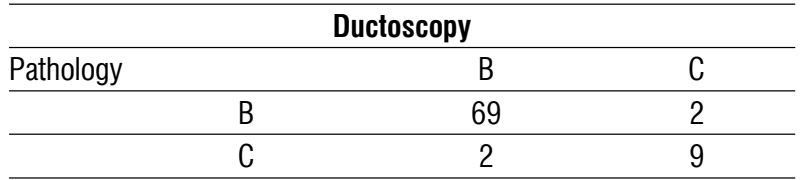

B: benign lesion, C: cancer or precancer lesion 
Table 3. Duct cytology sensitivity and specificity

\begin{tabular}{lccc}
\hline Authors & Sensitivity & Specificity & DL \& DB \\
\hline Pritt B. et al (2004) & $85 \%$ & $97 \%$ & \\
\hline Beechey-Newman et al (2005) & $87.5 \%$ & & $\sqrt{ }$ \\
\hline Liu GY et al (2008) & $94.2 \%$ & & \\
\hline Ohlinger R. et al (2014) & $58 \%$ & $85.2 \%$ & \\
\hline Yilmaz R et al (2017) & $95 \%$ & $40 \%$ & \\
\hline Zervoudis et al (2020) & $80 \%$ & $84 \%$ & $\sqrt{ }$ \\
\hline
\end{tabular}

ductoscopy coupled to duct lavage seems effective in the final diagnosis of unilateral nipple discharge (21).

Moreover considering that the previous studies used older ductoscopes, modern and thinner instruments (22) and the complementary brushing technique (9-10) are expected to offer greater sensitivity and accuracy and the method could alleviate the need of "aggressive" procedures (21). Moreover Interventional Ductoscopy could also be used to perform selective ductectomy as a minimal surgery procedure (23).

Nipple discharge may be linked to intraductal papillomas, papillomatosis, breast carcinoma, duct ectasia, mastitis, fibrocystic changes, and Paget's disease of the nipple (1). In bilateral multiducts nipple discharge usually ductoscopy is not indicated. On the contrary, in unilateral and from one duct discharge, the most common final diagnosis of the underlying pathology seems to be papilloma then duct ectasia and less frequently breast cancer and precancer lesions., according to our data. However, special consideration should be given to papillary carcinoma which may present as a unilateral nipple discharge that originates from one duct (14-15).

Moreover in other studies, a combination of histologic diagnoses were described, including papilloma with DCIS and papilloma with invasive ductal carcinoma (24). In our series we found in 3 cases only a combination of lesions and they were benign.

\section{Conclusion}

Ductoscopy, is an effective procedure for the successful evaluation of pathologic nipple discharge. The combination of Ductoscopy
Duct Lavage and Duct brushing increases the accuracy of the diagnosis. Technically these coupled techniques were effective in more than $96 \%$ of our patients enrolled for diagnosis of unilateral unipore pathological nipple discharge. Moreover in our series we obtained a concordance of $69 \%$ for all groups and $79 \%$ for the groups cancer or precancer lesions versus benign lesions. These values are high if compared to those in the literature.

In accord with expert centers in the world where these techniques are routinely performed and with our experience, we suggest to spread this procedure to explore patients with organic nipple discharge.

\section{Conflict of Interest Statement}

The authors of this study declare there are no conflicts of interest.

\section{References}

1. Zervoudis S., latrakis G., Economides P., Polyzos D., Navrozoglou I. Nipple discharge screening. Womens Health (Lond). 2010, 6:135-51.

2. Istomin $A$, Masarwah $A$, Pitkänen $M$, Joukainen $S$, Sutela $A$, Vanninen R. et al. Galactography is not an obsolete investigation in the evaluation of pathological nipple discharge. PLoS One 2018, 13:e0204326.

3. Manganaro L, D'Ambrosio I, Gigli S, Di Pastena F, Giraldi G, Tardioli $S$, et al. Breast MRI in Patients with Unilateral Bloody and SerousBloody Nipple Discharge: A Comparison with Galactography. 2015;2015:806368. doi: 10.1155/2015/806368. Epub 2015 Jan 22.

4. Schulz-Wendtland R, Preuss C, Fasching PA, Loehberg CR, Lux MP, Emons J. et al. Galactography with Tomosynthesis Technique (Galactomosynthesis) - Renaissance of a Method? Geburtshilfe Frauenheilkd. 2018;78:493-8.

5. Li XQ, Xu F, Lei CQ, Li J, Jiang HC. Accuracy for cytological evaluation in the detection of breast cancer among patients with pathologic nipple discharge: a PRISMA-compliant meta-analysis. Chin Med J (Engl). 2020;133:435-43.

6. Zervoudis S. A simple tool complementary for the diagnosis of breast diseases: the mammary pump. Breast J. 2003;9:445-7.

7. Leitch M, Ashfaq R. Discharges and Secretions of the nipple. The Breast 2018,57-78,e3.

8. Ohlinger R., Stomps A., Paepke S., Blohmer J.U., Grunwald S., Hahndorf W. et al. Ductoscopic detection of intraductal lesions in cases of pathologic nipple discharge in comparison with standard diagnostics: the German multicenter study. Oncol Res Treat. 2014; 37:628-32.

9. Beechey-Newman N, Kulkarni D, Kothari A, D'Arrlgo C, Culora G, Hamed $H$. et al. Breast duct microendoscopy in nipple discharge: microbrush improves cytology Surgical Endoscopy And Other Interventional Techniques volume 19. 2005. p. 1648-1651.

10. Zervoudis S, Tamer V, latrakis G, Bothou A, Tokou X, Augoulea A et al. Improving ductoscopy with duct lavage and duct brushing. Eur J Gynaecol Oncol. 2014;35:548-53.

11. Hadfield G.J. Noncosmetic operations for benign breast disease. 
World J Surg. 1989;13:757-60.

12. Lansac J, Lecomte $P$, Marret $H$. Gynécologie pour le praticien 8ème édition, Paris: Elsevier-Masson. 2012.

13. Sharma R, Dietz J, Wright H, Crowe J, DiNunzio A, Woletz J. et al. Comparative analysis of minimally invasive microductectomy versus major duct excision in patients with pathologic nipple discharge. J,Surgery 2005 0ct; 138: 591-6;596-7.

14. Zervoudis S, latrakis G, Navrozoglou I, Veduta A, Vladareanu R. Transnipple pyramidectomy in pathological nipple discharge: an original minimal surgery technique in a series of 80 cases. Eur $\mathrm{J}$ Gynaecol Oncol. 2007;28:307-9.

15. Makita M, Akiyama F, Gomi N, Iwase T, Kasumi F, Sakamoto G. Endoscopic and histologic findings of intraductal lesions presenting with nipple discharge. Breast J 2006, 12: S210-7.

16. De Censi A, Cazzaniga M, Gandini S, Casadio C, Chiapparini L, A Guerrieri Gonzaga A et al. Abstract P3-10-02: Presence of atypia in ductal lavage and risk of subsequent breast cancer in a prospective study, Abstracts: 2017 San Antonio Breast Cancer Symposium; December 5-9.

17. Filipe MD, Waaijer $L$, van der Pol C, van Diest PJ, Witkamp AJ. Interventional Ductoscopy as an Alternative for Major Duct Excision or Microdochectomy in Wome Suffering Pathologic Nipple Discharge: A Single-center Experience. Clin Breast Cancer
2020, pii: S1526-8209(19)30767-0.

18. Yamamoto D, Chiba T, Ishizuka M, Sueoka N, Yoshikawa K, Miyata M et al. Abnormal Nipple Discharge. Gan To Kagaku Ryoho 2019, 46:378-9.

19. Pritt B, Pang Y, Kellog M, Saint-John T, Elhosseyny A. Diagnostic value of nipple discharge. Cancer Cytopathology. 2004;102:233.

20. Yılmaz R, Bender O, Fatma Yabul C, Dursun M, Tunacı M. and Acunas G. Diagnosis of Nipple Discharge: Value of Magnetic Resonance Imaging and Ultrasonography in Comparison with Ductoscopy. Balkan Med J. 2017;34:119-126.

21. Chang YK, Chen CT, Wang M, Yang Y, Mark B, Zheng AQ et al. Breast Cancer 2020, doi: 10.1007/s12282-020-01051-w (Epub ahead of print).

22. Jacobs V, Kiechle M, Plattner B, Fischer T, Paepke S. Breast ductoscopy with a $0.55-\mathrm{mm}$ mini-endoscope for direct visualization of intraductal lesions. J Minim Invasive Gynecol. 2005;12(4):359-64.

23. Dietz JR, Crowe JP, Grundfest S, Arrigain S, Kim JA. Directed duct excision by using mammary ductoscopy in patients with pathologic nipple discharge. Surgery. 2002;132:582-7; discussion 587-8.

24. Ali MM. Diagnosis and surgical treatment of pathologic nipple discharge using ultrasound-guided wire localization of focal ductal dilatation. 2020;26(2):139-143. Epub 2019 Sep 11. 